\title{
The Effect of HR Development on Job Satisfaction, Work Motivation and Employee Performance at Dinas Dukcapil Office of Palopo City
}

\author{
Muh. Syaiful. S ${ }^{1}$, Sapar ${ }^{2}$, Muhammad Aqsa ${ }^{3}$ \\ \{muhammadsyaiful@student.umpalopo.ac.id,sapar@umpalopo.ac.id, \\ muhammadaqsa@umpalopo.ac.id\} \\ Postgraduate of Management, Universitas Muhammadiyah Palopo \\ Jalan Jendral Sudirman Km. 3. Binturu Kota Palopo, 91922, Indonesia
}

\begin{abstract}
This study aimed to determine the effect of human resource development on job satisfaction, work motivation and employee performance. The population in this study was 285 employees and a sample of 167 respondents. This research conducted at Dinas Kependudukan dan Pencatatan Sipil of Palopo City by using primary data collected through a questionnaire. The data analysis technique used was the Path Analysis technique and was operated through SPSS 25.0. The results show that motivation has a significant effect on job satisfaction, compensation has a significant effect on job satisfaction, job satisfaction has a significant effect on employee performance, motivation and compensation have a significant direct effect on employee performance, human resource development through job satisfaction has a significant effect on employee performance, compensation through job satisfaction on performance has no significant effect.
\end{abstract}

Keywords: Hr development, motivation, compensation, job satisfaction, employee performance

\section{Introduction}

Human resources are the most important part of the continuity of organizations in the era of globalization. Human resources have an important role in any organization. Although they are supported by devices and infrastructure, as well as other resources, but if they are not supported by reliable human resources, the activities of the organization will not be completed properly. This is supported from Suwatno's opinion [1] that human resources always have an active and leading role in every organization, because human resources are planners, participants, and determinants of organizational goals. Therefore, every organization needs to use professional human resources in every part of organization.

Organization or company is a means of activities carried out by people to achieve common goals. In this activity, each person or employee must have the ability to carry out their duties, authority and responsibilities based on their main duties and functions. Human resource development includes the task of optimizing the use of human resources owned by the organization, according to Kaswan [2] that Human resource development is a function that can be carried out independently or one of the main functions of the human resources department. Sutrisno (3) stated that human resource development can be completed through education and training to improve employee performance. Education is an investment in HR. Companies or organizations, to grow and develop in terms of human resource development, need to make the most effective investment in human resources to fulfill mental and spiritual needs. 
Training is a powerful tool that can overcome the challenges of an organization or company in the future and experience change so quickly. Human resource development needs to be carried out by organizations or companies to further improve services to the community this study conducted at Dinas Dukcapil of Palopo City.

Dinas Dukcapil Office of Palopo City is a government agency in the field of population and civil registration. The institution or agency needs to improve employee performance. When observations show that employee performance is still very low, it needs to be developed through education and training. This is consistent with the results of research conducted by Sahat Siregar (4), where the development of human resources affects employee performance. A study by Meiske (5) examine the impact of human resources in the Minahasa office on apparatus productivity. From the results of research that has been done it can be seen that the development of human resources has a positive and significant impact on employee work efficiency. Based on the background stated above, the researcher is interested in conducting research under the title: "The Effect of HR Development on Job Satisfaction, Work Motivation and Employee Performance at Dinas Dukcapil Office of Palopo City."

The purpose of this study was to determine how the relationship and influence between resource development on motivation, job satisfaction and employee performance. For this reason, the problem can be formulated in this study are: how the influence of resource development and job satisfaction on work motivation and employee performance either partially or simultaneously.

\section{Literature Review}

\subsection{HR Development}

Through existing employee development activities, the development of human resources aims to reduce the dependency of regional government apparatus organizations on the selection and assigning of new employees. If the employee is well developed, vacant positions will be filled internally through human resource planning activities. Employee promotions and transfers can also show employees that they have a career level, not just an usual job. The government can get benefit from improving the sustainability of regional apparatus organizations, as well as greater employee commitment to local government institutions.

The definition of human resource development according to Handoko (6) is the development of human resources has a broader scope to enhance and deepen knowledge, skills, attitudes and traits and personality in order to prepare employees for their professional duties in the future.

\subsection{Job Satisfaction}

Rivai (7) defines job satisfaction as an assessment that describes someone with a sense of happiness or dissatisfaction, satisfaction or dissatisfaction with work at work. Robbins (8) defines job satisfaction as positive feelings related to work, which are the result of assessing their characteristics. According to George and Jones (9), job satisfaction is the perception of employees or employees about the current working conditions at work.

\subsection{Motivation}


High and low employee performance is certainly determined by factors that directly or indirectly influence it. Motivation is the process of moving or encouraging someone to do something to achieve the expected goals. Mangkunegara (10) shows that the factors that influence the achievement of maximum performance are motivational factors.

Definition Motivation is a condition that encourages others to carry out their tasks based on their functions within the organization or company. Motivation can also be defined as behavior that affects the normal behavior of others in order to behave regularly.

According to Mangkunegara (10), motivation is an encouragement to the needs of employees that need to be met so that employees can adjust to their environment, while motivation is a condition that encourages employees to be able to achieve their motive goals. according to Wibowo (12) motivational techniques must be able to ensure that the environment in which employees work fulfills a number of important human needs.

Based on the opinions of the experts above, it can be concluded that motivation is an independent encouragement that can stimulate people's enthusiasm and determine behavior to achieve the goals. To achieve the goals of the company or organization, the motivation of leaders have a very important role in the behavior patterns of the employees or workers they lead.

\subsection{Performance}

Performance is the result of the quality and quantity of work carried out by employees based on their main tasks and functions assigned to them (Mangkunegara (10)). Another definition of performance is the result of someone completing a job based on the main tasks and functions and requirements of a job.

A job also has certain requirements to achieve the objectives as far as possible. This is also mentioned as work standard (Bangun (11)). Improved performance is something that is expected by all organizations or companies, but it is not easy for organizations or companies to improve the performance of employees or workers. Therefore, a performance management system is needed to improve employee performance. A system can provide an overview of a company's performance evaluation of employees or workers, the purpose and benefits of performance evaluation, performance evaluation of employees or workers and whether the objectives of the organization or company can be achieved.

Bangun (11) define a performance management system as the process of identifying, measuring and evaluating the performance of employees or employees in an organization or company. Performance evaluation is the process carried out by an organization or company to assess or evaluate the success of employees or employees in carrying out their main tasks and functions. Performance evaluation is the process carried out by an organization or company to assess or evaluate the success of employees or employees in carrying out their main tasks and functions. If exceeded, it can be said that the performance of employees or workers included in the good category by the organization or company. On the other hand, if the work standards are not properly or the performance is very poor, it is included in the category of poor performance. To facilitate performance evaluation, work standards must be measured and clearly understood. Sa job can be measured by the quantity, quality, timeliness of implementation, presence or presence and the ability to work collaboratively which is demanded by a particular job.

Based on the above theory, researchers applied the conceptual framework of research as follows:

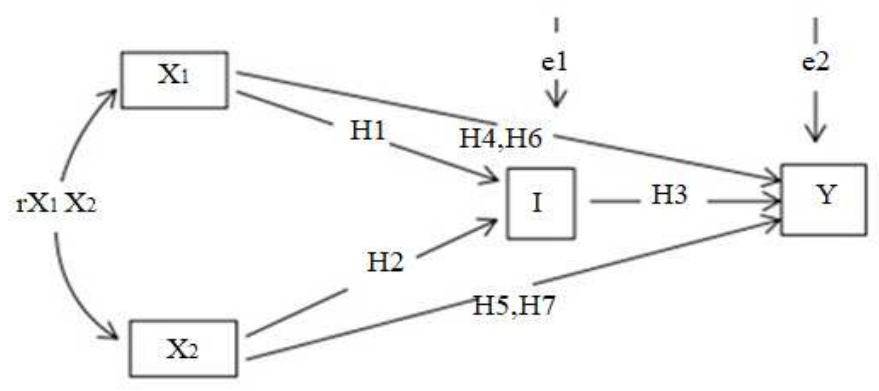


Fig.1. conceptual framework

\section{Method}

This study applied quantitative method with path analysis, where the research variables are motivation, employee performance, job satisfaction and HR Development. The population in this study was employees at Dinas Dukcapil Office of Palopo City namely 285 people. The sampling technique using the Slovin formula by taking 167 respondents . Data analysis techniques used were the validity test, reliability test, test the level of achievement of respondents, normality test, linearity test, multicollinearity test, heteroscedasticity test, and path analysis.

\section{Result And Discussion}

R Square results of job satisfaction (I) the results of data processing using SPSS 25.0 are as follows:

\begin{tabular}{ccccc} 
& & \multicolumn{3}{c}{ Table 1. Model Summary } \\
\hline \multirow{2}{*}{ Model } & \multirow{2}{*}{$\mathrm{R}$} & $\begin{array}{c}\mathrm{R} \\
\text { Square }\end{array}$ & $\begin{array}{c}\text { Adjusted R } \\
\text { Square }\end{array}$ & $\begin{array}{c}\text { Std. Error of } \\
\text { the Estimate }\end{array}$ \\
\hline 1 & $834^{\mathrm{a}}$ & 695 & 692 & 3.55892 \\
\hline
\end{tabular}

a. Predictors: (Constant), Performance, Motivation

b. Dependent Variable: HR Development

Source: Primary data processed with SPSS 25.0, 2020

The results of the performance of R Square (Y) data processing using SPSS 25.0 are as follows:

Table 2. Model Summary ${ }^{\mathrm{a}}$

\begin{tabular}{ccccc}
\hline Model & $\mathrm{R}$ & $\begin{array}{c}\mathrm{R} \\
\text { Square }\end{array}$ & $\begin{array}{c}\text { Adjusted R } \\
\text { Square }\end{array}$ & $\begin{array}{c}\text { Std. Error of } \\
\text { the Estimate }\end{array}$ \\
\hline 1 & $745^{\mathrm{a}}$ & 554 & 546 & 2.79131 \\
\hline
\end{tabular}

a. Predictors: (Constant), Job Satisfaction, Performance, Motivation

b. Dependent Variable: HR Development

Source: Primary data processed with SPSS 25.0, 2020

The results of the effects of regression of motivation (X1), Performance (X2) and job satisfaction (I) on HR Development (Y) using SPSS 25.0 are as follows: 
Table 3. Cofficients ${ }^{\mathrm{a}}$

\begin{tabular}{|c|c|c|c|c|c|}
\hline \multirow[t]{2}{*}{ Model } & \multicolumn{2}{|c|}{$\begin{array}{l}\text { Unstandardized } \\
\text { Cofficients }\end{array}$} & \multirow{2}{*}{$\begin{array}{c}\text { Standardized } \\
\text { Cofficients } \\
\text { Beta } \\
\end{array}$} & \multirow[t]{2}{*}{$\mathrm{t}$} & \multirow[t]{2}{*}{ Siq } \\
\hline & $\mathrm{B}$ & Std Error & & & \\
\hline (Constant) & 19.233 & 1.853 & & 10.37 & 000 \\
\hline Motivation & 164 & 080 & 182 & 6 & 041 \\
\hline Performance & 136 & 063 & 167 & 2.063 & 034 \\
\hline Jod Satisfaction & 296 & 061 & 458 & 2.138 & 000 \\
\hline & & & & 4.839 & \\
\hline
\end{tabular}

Dependent Variable: HR Development

Source: Primary data processed with SPSS 25.0, 2020

\section{Conclusion}

The conclusion that can be drawn based on data analysis is that resource development has an influence on motivation, resource development also has an influence on performance either directly or through motivation as an intervening variable. Job satisfaction also has an influence on motivation, job satisfaction also has an influence on performance either directly or through motivation as an intervening variable. Simultaneously resource development and job satisfaction have an influence on motivation, also simultaneously have an effect on performance through motivation as an intervening variable.

This shows that the development of resources can improve employee abilities so as to motivate employees to show optimal performance, so as to increase employee job satisfaction that arises through increasing knowledge and abilities through training and workshops attended by employees.

\section{Acknowledgments}

Researcher would like to thank to all lecturers of Universitas Muhammadiyah of Palopo for helping and giving support in this research.

\section{References}

[1] Suwatno H. Manajemen SDM dalam organisasi publik dan bisnis. Bandung: Alfabeta; 2011. 16 p.

[2] Kaswan. Pelatihan dan Pengembangan SDM. Bandung: Alfabeta; 2011.2 p.

[3] Sutrisno E. Manajemen Sumber Daya Manusia. Jakarta: Kencana Prenada Media Group; 2009. $67 \mathrm{p}$.

[4] Sahat S. Pengaruh Pengembangan Sumber Daya Manusia Terhadap Pegawai. Universitas Sumatera Utara, Fakultas Ilmu Sosial dan Ilmu Politik. 2009;

[5] Rembang MM. Pengaruh Pengembangan Sumber Daya Manusia Terhadap Produktivitas Kerja Aparatur. HOLISTIK, J Soc Cult. 2008;

[6] Handoko TH. Manajemen Personalia dan Sumber Daya Manusia. Yogyakarta: BPFE Yogyakarta; 
2001.

[7] Rivai. Manajemen Sumber Daya Manusia untuk Perusahaan dari Teori ke Praktik. Jakarta: Raja Grafindo Persada; 2010.

[8] Robbins SP and TAH. Perilaku Organisasi (Organizational Behavior). Vol. 10. Jakarta: Salemba Empat; 2011.

[9] George and Jones. Organizational Behavior. AS: Prentice Hall; 2002.

[10] Mangkunegara A. Manajemen Sumber Daya Manusia Perusahaan. Bandung: Pemuda Rosdakarya; 2013.

[11] Bangun W. Manajemen Sumber Daya Manusia. Jakarta: Erlangga; 2012. 313 p.

[12] Wibowo. Manajemen kinerja. Jakarta: PT Rajagrafindo Persada; 2014. 324 p. 